\title{
Effect of health care Servise on BPJS Health Patient Satisfaction in Padang's Hospitals
}

\author{
Faisal Marzuki ${ }^{1}$, Atika Pradana Yuntarisa ${ }^{2}$, Miftachus Sholikah ${ }^{3}$ \\ \{faisal@upnvj.ac.id', atikapradana@gmail.com².mieft.solikah@gmail.com\} \\ Universitas Pembangunan Nasional Veteran, Jakarta ${ }^{12}$, IAI Pangeran Diponegoro Nganjuk ${ }^{3}$
}

\begin{abstract}
The purpose of this study is to observe the services and the level of satisfaction of outpatient as the Health BPJS participants in hospitals. This study uses a survey method to the BPJS' patients in hospitals. The sample is taken by using purposive sampling method in which the total sample is 65 patients. The questionnaire is used to retrieve data. The data is analyzed by using correlation. The results of this study concludes that there is a significant relationship between hospitals and patient satisfaction of Health BPJS.
\end{abstract}

Keywords: Health Care Services, Patient Satisfaction, Health BPJS.

\section{Introduction}

This Health is a human basic need to be able to live better and more productive. For that reason, it is necessary to hand over health services which if the costs can be handled and the qualities can help the civil society [1] The health status of the citizen in a country is affected by the health facilities themselves. The health facilities consist of the health care facility and government-owned health education institution that provide health workers. Health care facilities consist of community health centers (puskesmas), hospitals, and community-based health efforts (UKBM).

After the program promoted by the Social Security Organizing Agency (BPJS) from the government, the community can more easily use health services started from people in low economic status to people in high economic status from primary to secondary services. Hospital which is one of the health care facilities is expected to provide the effective and efficient services. Patient satisfaction is the patient's feeling that comes out as the result of the performance of health services obtained after the patient compared it with what he had expected previously [1]. This satisfaction is one of the most important indicators in health services, but satisfaction is often overlooked or forgotten. Patients will be satisfied if the performance of health services that they get is the same or exceeds the expectations [2] Dissatisfaction or patients' disappointment will emerge if the service they feel is not in accordance with their expectations. When patients get satisfaction, they will probably always come to that health facility. Patients will always look for health services in health facilities whose performance of delivery service can meet expectations or does not disappoint patients [3].

In measuring the quality of service (service quality), people can use the dimensions of service quality [4] There are five characteristics for that dimensions, the first is tangibles (direct evidence) including physical facilities, equipment, employees and means of communication. The second is reliability. It is the ability to provide promised services immediately, accurately 
and satisfactorily. The third is responsiveness. It is the desire of the staff to take care of patients and provide responsive services. The fourth is assurance. It is a guarantee that includes knowledge, ability, politeness and trustworthiness that staff possesses and that is free from danger, risk or doubt. And the fifth is empathy (concern). It is in the form of ease in establishing good communication relationships that show personal attention between employees and clients and in understanding the needs of patients.

From the results of preliminary studies conducted at Padang Pariaman Hospital through interviews to the patients who use BPJS, the researcher found several views related to BPJS: (a) BPJS respondents stated that three of five BPJS customers complained that they were better off paying regularly because they did not want to be confused in taking care of BPJS. (b) Two of five BPJS patients stated that if they use BPJS they are afraid of not being served optimally. (c) Other complaints from BPJS users interviewed stated that, two of five patients interviewed were not comfortable with the services of the doctors on duty at the hospital. If using BPJS, they feel that sometimes the doctors in charge spoke loudly and showed unfriendly faces that made them not comfortable with the services provided. As an effort to meet the needs of the community to obtain qualified health services, the health BPJS will continue to expand the network of health facility partners throughout Indonesia.

\section{Literatur Review}

Health care service is the right of everyone as well as an effort that is carried out individually or together in an organization to maintain and to improve health, to prevent and to cure diseases and to restore health not only individuals, families, groups but also communities [1]. Generally health services consist of two forms, namely: individual health services (medical services). These health services are carried out by individuals independently (self-care), and family (family care) or member of community groups that aim to cure diseases and to restore personal and family health. These individual service efforts are carried out at health care institutions called hospitals, maternity clinics, and independent practices. Public health services are organized by groups and communities that aim to maintain and to improve health that refers to the promoted and preventive actions.

Patients' satisfaction is the patients' response to the fulfillment of his needs. It means that the assessment of a form of privilege of an item or service or goods/service itself provides a level of convenience associated with the need fulfillment, including the meeting of needs below expectations or even exceeding the patient expectations [5]. However, costumers' satisfaction is the level of one's feelings after comparing the performance (or results) that they perceive if it is compared with expectations which are basically intangible and do not result in ownership of something. Five main factors that need to be considered in relation to the customer satisfaction, among others, the quality of consumer products. Customers will be satisfied if their evaluation results indicate that the product they are using is of high quality. The next is service quality. Customers will be satisfied if they get good or appropriate service as well as what they hope. The emotional consumers feel satisfied when people praise him for obtaining high quality services and the willingness of patients to re-use the service [6].

Patient satisfaction can be influenced by several things. Aspects that can affect patient satisfaction consist of: product characteristics, price, service, location, facilities, image, visual design, atmosphere, and communication. There are five factors that can affect client satisfaction, including: Physical Facilities (Tangible), Reliability, Responsiveness, Assurance, and Concern 
(Empathy) [2] Measuring the level of satisfaction of patients is to determine the level of patient satisfaction classified in several levels as follows: very satisfied, satisfied, quite satisfied, and not satisfied.

\section{Method}

The type of research used is quantitative by using the survey method. Data collection technique is questionnaires. The sampling technique used is a purposive sampling method with a population of 188 patients. Once calculated by using the Slovin formula, the number of samples was 65 patients.

\section{$4 \quad$ Result and Discussion}

\subsection{Result of Research}

This study is about nursing services with satisfaction of BPJS participants of outpatient policlinic in Padang Pariaman Hospital conducted on December 27, 2018 in the Regional General Hospital with the total sample of 65 respondents. At the time of the research, there were around 3 people patients who did not meet the inclusion criteria because they were not willing to be the respondents. Therefore, the researcher looked for other patients so that the targeted number of samples was fulfilled.

\subsection{Health Service}

Based on the results of research conducted on 65 respondents in the policlinic outpatient in Padang Pariaman Hospital, it can be seen from the results of frequency distribution in table 4.1. It states that the respondents showed the most perceived good quality of nursing services is as many as 57 people $(88 \%)$ while 8 people $(12 \%)$ showed that the quality of nursing services is not good.

Table 1. Frequency Distribution of health services in policlinic of Regional General Hospital in Padang Pariaman

\begin{tabular}{lll}
\hline Health service & Number & Percentage \\
\hline Good & 57 & $88 \%$ \\
Not good & 8 & $12 \%$ \\
Total & 65 & $100 \%$ \\
\hline
\end{tabular}

\subsection{Patient Satisfaction}


Based on the results of research conducted on 65 respondents in the outpatient policlinic of Padang Pariaman Hospital, it can be understood from the results of the frequency distribution in table 2. It can be seen that the distribution of respondents based on patient satisfaction of BPJS participants in Padang Pariaman Hospital showed that there are 41 patients expressing the satisfaction (63\%) while those who are not satisfied are 24 people (37\%). This fact was obtained from the results of interviews with BPJS patients in Padang Pariaman Hospital stating the patient's complaints stated as follows: 1) The BPJS respondents stated that 3 of 5 BPJS customers complained that it was better to pay because they did not want to get complicated to deal with BPJS. 2) Among 2 of 5 BPJS patients stated that if they use BPJS they are afraid that they will not be served optimally. 3) Other complaints from BPJS users interviewed stated that 2 of 5 patients interviewed felt uncomfortable with the services of the doctors on duty at the hospital, if using BPJS, that sometimes the doctors in charge spoke loudly and unfriendly faces, the patients felt uncomfortable with the services provided. The following is the recapitulation of respondent data as shown in table 2 .

Table 2. Frequency Distibution of patients satisfaction in policlinic of Regional General Hospital in Padang Pariaman

\begin{tabular}{lll}
\hline Health service & Number & Percentage \\
\hline Satisfied & 55 & $84,6 \%$ \\
Dissatisfied & 10 & $15,4 \%$ \\
Total & 65 & $100 \%$ \\
\hline
\end{tabular}

\subsection{Discussion}

Based on research conducted at the outpatient policlinic of Padang Pariaman Hospital for health services to the Health BPJS participants in Padang Pariaman Hospital, it can be seen from the total of 65 respondents. As many as 57 respondents $(88 \%)$ said they received good health services in Padang Pariaman Hospital while 8 respondents (12\%) stated that they received poor service at the Regional General Hospital.

Based on research conducted at the outpatient policlinic at Padang Pariaman Hospital towards patient satisfaction in the Regional General Hospital, the results shows that 65 respondents $(84,6) 55$ people were satisfied with the services provided at Padang Pariaman Hospital and 10 people $(15,4 \%)$ were dissatisfied of the quality of health services carried out by Padang Pariaman Hospital. Patient satisfaction is also influenced by the patient's experience in obtaining previous services.

\section{Conclusion}

Research on Health Services and Patient Satisfaction in outpatient policlinic for Health BPJS Participants in the Padang Pariaman Regional General Hospital in 2018 found that hospital services for BPJS patients were classified as good and the satisfaction of health services was not only good but also satisfying for patients. 


\section{Suggestion}

Hopefully the results of this study can be used as material input and consideration for the future for health workers, as well as input for improving the quality of nursing services in order to meet the expectations and satisfaction of patients, so they can determine the next steps that can be taken in taking wisdom.

\section{References}

[1] S. Bostan, T. Acuner, and G. G. Yilmaz, 'Patient (Customer) Expectations in Hospitals", Heal. Polty, vol. 82, no. 62-70, pp. 62-70, 2007.

[2] B. Graham, 'Defining and Measuring Patient Satisfaction', J. Hand Surg. Am., vol. 41, no. 9, pp. 929-931, 2016.

[3] K. A. A. Calabro, M. V. V Raval, and D. H. H. Rothstein, 'Importance of patient and family satisfaction in perioperative care', Semin. Pediatr. Surg., vol. 27, no. 2, pp. 114-120, 2018.

[4] J. H. Y. Ng and B. H. K. Luk, 'Patient satisfaction: concept analysis in the healthcare context', Patient Educ. Couns., 2018.

[5] C. G. Martín, R. A. G. Morato, N. D. L. R. Cortés, and P. Holguín, 'Patient satisfaction in a Spanish burn unit', Burns, pp. 1-7, 2018.

[6] C. K. Yim, L. Shumate, S. H. Barnett, and I. M. Leitman, 'Cindi K Yim and others, 'Health Literacy Assessment and Patient Satisfaction in Surgical Practice', Ann. Med. Surg., 2018. 